\title{
多変量解析法
}

\section{多変量解析法 $(2)$}

佐藤信

\section{3. 回帰之相関}

多变量解析法を理解するためには, 回州と相関についての知識が是非とも必要である。以下, なるべ く数学的な表現を避けて，その概念を説明しておこう。

\section{発端は進化論に始る}

動植物の分類学の基礎を築いた C.リンネは, 18 世紀の半ば頃, 「種の不変」を唱えた。この考え方 は, 現存する動物は, それが地上に出現した時点から, 現在と同じ形態をしていたとする聖書の宇宙創 造説に一致するために, 当時のヨーロッパの支配階級であった僧侣・貴族にとっては, 甚だ好結果な思 想であったと言光よう。

しかしながら，その後の化石研究の進歩などから，この考光方には矛盾が否定できなくなり，遂に， 約 100 年後の 1859 年にC. ダーウインによる「種の起源」の出版となり, 進化論が登場したのである。 この進化論が当時の英国社会に与兄た影響の大ささは,「種の起源」初版 1,250 部が即日売り切れたこ と，1860 年にオックスフォード大学で開かれた英国学術協会での僧正ウィルバーフォースとダーウィ ン学説の支持者ハックスリとの論争などによって推察することができる。

この進化論に多大の影響を受けたのが，ダーウィンのいとこであり，同時に良い協同研究者でもあっ たF.ゴールトン（1822〜1911 年）である。ゴールトンの研究の目的は, 進化の原理を積極的に利用す ることによって, 人類を向上させることであって, 優良な子孫を残すための具体的な施策として優生学 を提晿し，1911 年に没した時には，ロンドン大学に多額の基金を寄付して，その生涯の目的であった 優生学の講座を初めて設けた。

彼は，人間の能力をはじめ，人間の多くの特性について計測したが，ここで人間の身長の問題をとり あげてみよら。一般に, 親の身長と子の身長との間には関係が嵓ると考党られているが, むし, ノッポ の親からは常に同様にノッポの子が生れ, チビの親からは同様にチビの子が生れるというような傾向が あるならば，人類の身長はある一定の範团を保つことができないはずである。なぜならば，ある身長の 親から何らかの理由で親よりもノッポ（またはチビ）の子が生れたとき，その身長がそのまま子孫受 けつがれ，さらにまた何らかの理由で親よりもノッポ（またはチビ）の子が生れるといらことがくり返 されるならば，人類の身長は巨人から小市で，その範囲を一方的に昖大するはずではないか。それに もかかわらず，人類が一定範囲の身長を保っているのはなぜだろらかという疑問を生じる。この疑問に 対して,ゴールトンは次のような答を発見したのである。

\section{ゴールトンの研究}

第 2 図は，親の身長と，その子が成人したときの身長の関係を示したものである。ただし，ここでは 次のような操作が施してある。

（イ）女子の身長は 1.08 倍して, 男子の身長と同等に扱う。（口）親の身長は, 両親の平均身長をと る。(ハ) 子の身長は, 同一の両親から生れた子供たちの成人時の身長の平均をとる。（二）図に示した 身長の值は，実際の身長から 68.25 インチを引いた值である。 


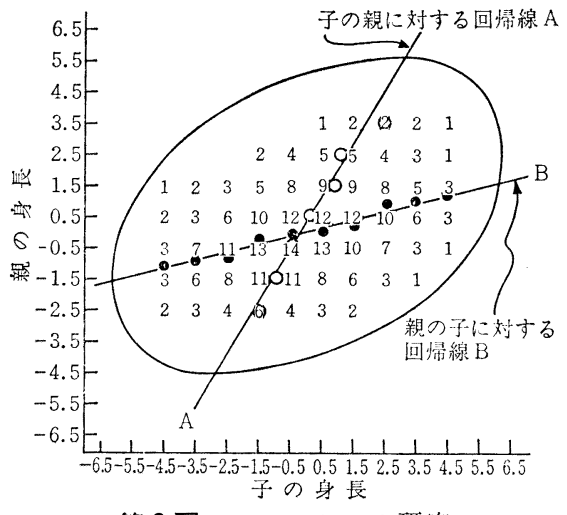

第2図コールトンの研究

さてここで，○印は，同一身長の親から生れた子供の平均 身長, つまりヨコ行の平均值を示している。たと光ば第 1 行 の場合には,

$$
\begin{aligned}
& (0.5 \times 1+1.5 \times 2+2.5 \times 2+3.5 \times 2+4.5 \times 1) \\
\div & (1+2+2+2+1)=2.5
\end{aligned}
$$

となる。そこで，この○印を結えでみるとほぼ直線になるこ と, そればかりでなく, ノッポの親から生机た子供は, やは りノッポではあるが，その平均身長は親の身長より低く，チ ビの親から生れた子供はやはりチビではあるが，その平均身 長は親より高いことがわかる。

これが，人類の身長が一定の範围に和さまっている理由で あり，ゴールトンはこの直線 Aを「親に対する子の回帰線」

と呼んだ。つまり，回帰とは先祖が党りを意味している。

同様に，一定身長の子供を生んだ親の平均身長，つまりタテ列の平均值を求めたのがの印であり，こ れを結んだ直線 $\mathrm{B}$ は, 子に対する親の回帰線というべきである。このように, 回帰線には 2 本あること になる。もちろん, 子供から親が生れるということはないから, 子に対する親の回帰線というのは, 単 に数学的な関係を示すにすぎない。

\section{回帰と相関の図による説明}

このようにしてゴールトンは，回帰といら新しい現象を発見したが，彼はさらに，第 2 図のデータの 散布状態が楕円形をしていることにも注意を払い，親の身長と子の身長の間のユルイ関係，すなわち相 関という新しい概念を生みだしたのである。

そしてこのゴールトンの研究は, 彼の協力者であるK.ピアソン（1857〜1936 年）によって受けつが れ，今日われわれが単に相関係数と呼んでいるピアソンの積率相関係数が導びかれたのである。

この回帰と相関という概念は, 多変量解析法のなかで重要な基礎となっている。そこで, もら少し説 明を加えておこう。

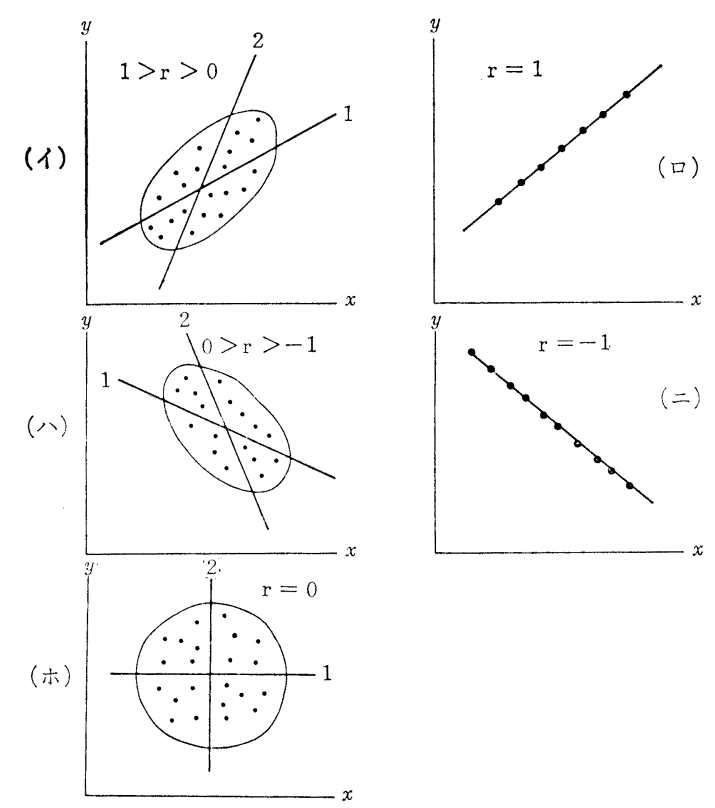

第 3 図 データの散布図回㷌去，相関係数の関係

親の身長と子の身長といったよらな間題にかぎら ず,これを一般的に $x$ と $y$ という 2 つの変量として 示したのが第 3 図である。ただし，点は各々のデー タの位置を示し，このような図を散布図という。ま た直線 1 は, $x$ に対する $y$ の回帰, $\hat{y}=a+b x$ そ示 し, 直線 2 は $y$ に対する $x$ の回帰, $\hat{x}=a^{\prime}+b^{\prime} y$ を示 के。

図(イ)では,データは右上りの棈円の中に散布 し，このときピアソンの相関係数 $r$ は 1 と 0 の間の 值をとる。そして，rが1に近づく注ど，2本の回 鹵線 1 と 2 は次第に近づき, 遂に重って 1 本になっ たときに，r=1 となり，図（口）のよらに, データ は直線の上に完全に並ぶことになる。

図(八)と(二)については, 直線の傾きは逆であ り，rの值は負であるが，上と同様なことがいえ る。

そして（ホ)のように $x$ と $y$ の関係が独立である とき，直線 1 と 2 は直交し，このとき $r=0$, そし 
てデータは棈円ではなく円の中にチラバルことになる。

さらに，相関係数 $r$ は， 2 本の回帰式の回帰係数 $b$ と $b^{\prime}$ の幾何平均になっている。すなわち,

$$
r=\sqrt{b} b^{\prime}
$$

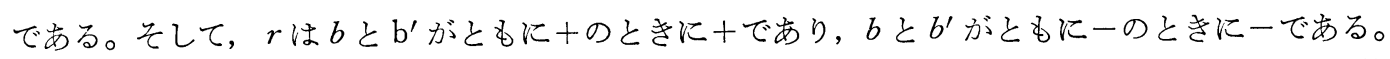

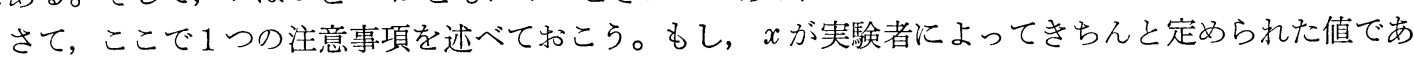
り，yのみが観湘值（測定值）であるなような場合，たと学ば，比色定量のための検量線をつくるよう なときには，物質量 $x$ に対する反応量 $y$ の回帰だけが必要であり， $x$ の $y$ に対する回帰式は用いない。 $x$ も $y$ ももに観測值であるときにかぎり, 二つの回帰式が必要になる。前者の場合を回帰のモデル I , 後者の場合をモデルII と言う。相関といら概念は，モデルIのときにだけ意味をもつことになる。

\section{4. 推定する}

\section{重回帰分析法}

回帰式の考え方：前章で述べたように, ゴールトンは, 同一身長の親から生れた子供の平均身長を結 ぶことによって, 親に対する子の回帰線を求めた。しかし現在は, もっと理論的にガッチリしたスマー トな方法で求める。

すなわち, 回畄式 $\hat{y}=a+b x$ の $a$ とを求めるためには, 最小二乗法と呼ばれる方法を用いる。最小 二乗法とは, 実測值 $y_{\imath}$ と推定值 $\hat{y}_{\imath}$ の差の 2 乗の総和,

$$
\Sigma\left(y_{i}-\hat{y}_{i}\right)^{2}
$$

を最小にするように $a$ とを決める方法であって，第 4 図で説明するならば，

$$
\sum e_{i}{ }^{2}=e_{1}{ }^{2}+e^{2}{ }_{2}+e_{3}{ }^{2}+e_{4}{ }^{2}
$$

が最小となるように直線をあてはめることを意味する。

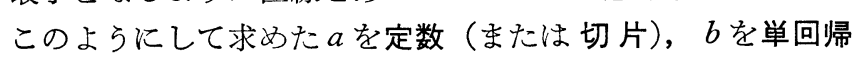

係数といら。

第 4 図の(イ)は， $x$ に対する $y$ の回帰式を求める場合，(口） は $y$ に対する $x$ の回帰式を求める場合である。(イ)では, $e$ を 垂直方向, (口)では水平方向の差として考えている点に注意し なければならない。

この場合, 説明変数 $x$ が 1 個であるから単回帰分析と呼ばれ るが，（例 8 ）のように説明变数の数を 2 個, あるいはそれ以 上に拡張することができる。その一般的な形は，すでに前号で (式 4)として示したように,

$$
\hat{y}=a_{0}+a_{1} x_{1}+\cdots+a_{p} x_{p}
$$

となる。ここで $a_{0}$ は定数, $a_{1} \sim a_{p}$ は説明変数 $x_{1} \sim x_{p}$ にかける 重みであり，偏回帰係数と呼ばれ，(式 4)を求めることを重回 帰分析といら。このとき， $a_{0} \sim a_{p}$ を求める考光方の原理が, 最小二乗法に基いていることはいらまでもない。

重相関係数, 決定係数：さて，(式 4)によって与光られる $\hat{y}$ は, 実際の観測によって得られた值 $y$ の推定值である。したが って，(式 4)がどれほど良い推定式であるか，つまり，yと辛 がどれほど良く一致するかが重要な問題になってくる。

そのことを確かめるためには，実際に(式 4)によって得られ た $\hat{y} の$ 值とyの值のくちがいを計算してみればよい。さらにま た，その一致（くいちがいと言ってもよい）の程度を測るモ）

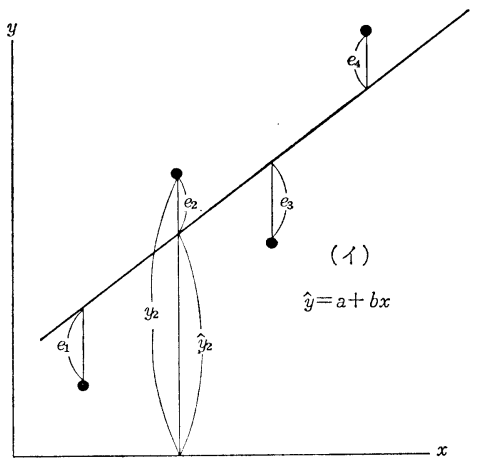

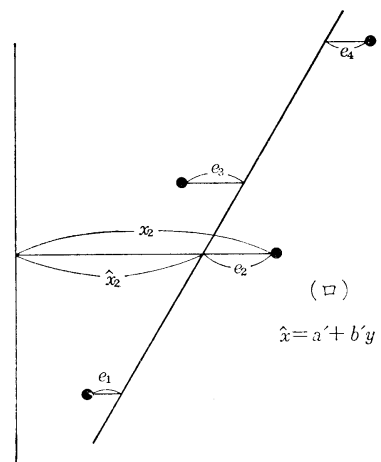

第4図 $x$ に対する $y$ の回帰式(イ) と, $y$ に対する回褕式(口)の 関係 


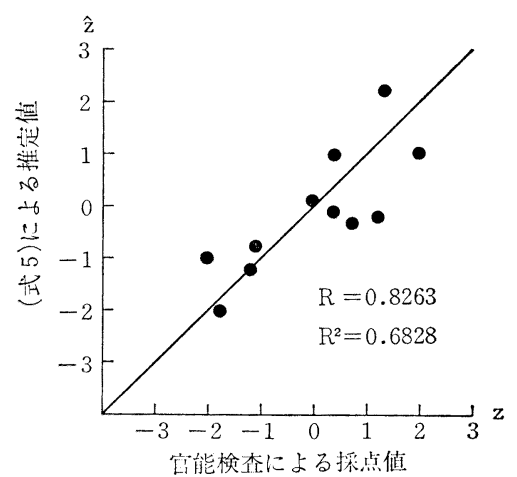

第 5 図清酒の味の濃淡に関する観

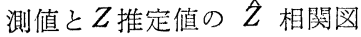

サシの一つとして，重相関係数や決定係数などがある。以下， 実例によって説明してみよう。

（例 9）清酒の味の濃淡；(例 8) では, 清酒の甘辛度（Y) を, 直糖分 $(S)$ と酸度 $(A)$ によって推定する式を紹介した。同 様に, 清酒の味の濃淡もこの両者によって推定することができ る。その推定式は次のと打りである7 。

$$
\hat{Z}=0.42 S+1.88 A-4.44
$$

この式の推定の精度をみるために, まず横軸に官能検査によ って得られた採点（専門パネルの平均值） $Z$ をとり, 縦軸に (式 5 ) によって計算した推 定值 $\hat{Z}$ をとって散布図を描いてみ ると，第 5 図のようになった。このとき，推定の䛊差が全くな ければ，各々の酒に対応する黒丸は，すべて原点をと和る傾き 45度の直線の上にのるはずである。図では, ほぼ直線の近くに散布している。

さて，(式 4) に示した $a_{0} \sim a_{p}$ は, $y$ と $\hat{y}$ (この例では $Z$ と $\hat{Z}$ ) の差の 2 乗の総和が最小になるように 決められるが，このことはまた，yと多の相関係数が最大になるよらにきめることを意味する。

したがって, $y$ と $\hat{y}$ の一致の程度は, $y$ と $\hat{y}$ の相関係数の大きさによって判断することができよう。 そこで, 第 5 図のデータについて相関係数 $R$ を計算してみると， $R=0.8263$ となった。このRを，重相 関係数という。

さらにまた，この重相関係数を 2 乗した $R^{2}$ のとを，決定係数，奇与率，説明変動率などと呼ぶ。 その理由は， $R^{2}$ が次のような内容をもつからである。

$$
R^{2}=\frac{\text { 回帰による平方和 }}{\text { 全体の平方和 }}
$$

(式 5 )について $R^{2}$ を求めると, 0.6828 となる。この $R^{2}$ ことを, 説明の程度といらことも市るが, それは説明変数によって被説明変数が説明できる程度といら意味である。すなわちこの例では, 清酒の 味の濃淡 $Z$ は, 糖量 $S$ と酸度 $A$ によって, その $68.3 \%$ が説明されるということがでさる。なお，(例 8 ）の甘辛度の決定係数は， $R^{2}=0.805$ であって, 濃淡度の場合よりも説明の程度が高い。

（例10）清酒の味の熟度の予測式; 清酒を $40^{\circ} \mathrm{C} て ゙ 60$ 日間貯蔵したときの味の熟度（官能值Y）劣被 説明変数とし，12 個の化学成分のなかから説明变数を選んで，次のよらな予測式をつくった

$$
\hat{Y}=0.1819-0.07 X_{1}+0.005 X_{2}+1.308 X_{3}
$$

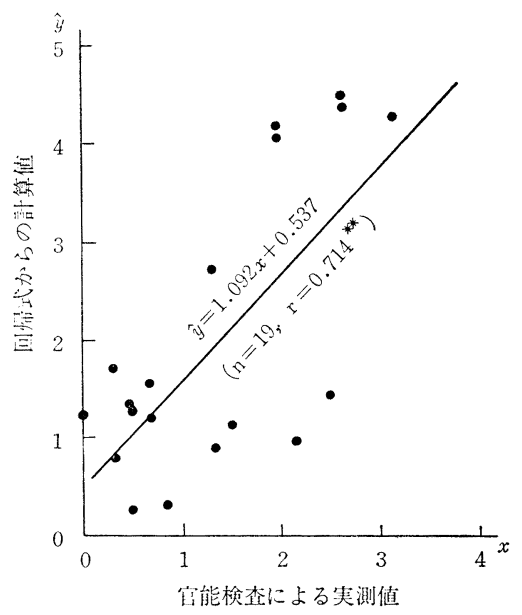

第 6 図味の熟度の回㷌式の妥当性

ただし， $X_{1}$ はアセトアルデヒド ppm, $X_{2}$ はピルビン酸 $\mathrm{ppm}$, $X_{3}$ はフェリクリシン含量である。この式の重相関係数 $R$ は 0.9466 で, 決定係数 $R^{2}$ は 0.896 であった。つまり, 説明変動 率は 89.6\% とかなり良い。しかしながら，これはこの予測式 を作るときに用いた 13 個の試料比対するアテハマリの良さを 示するのである。

そこで，この予測式の真の信頼度を知るためには，予測式を 作るときに用いた試料とは別の試料について検討する必要があ る。その結果を示したのが第 6 図で, この場合， $R=0.714$, $R^{2}=0.510$ となって説明の程度がかなり覀くなっている。

このように, 一般に, 予測式をつくるときに用いた試料に対 する説明の程度よりも, 別の試料に対する説明の程度の方が小 さくなるのが普通である。

説明変数の選び方：再び（式 4）をとりあげて，式中の説明 
変数の数 $p$ につて考えてみよう。いま，この式の重み $a_{0} \sim a_{p}$ をきめるために使うもとのデータが $n$ 組あるとする。つまり, 被説明变数 $y$ と説明变数 $x_{1} \sim x_{p}$ の組が $n$ 個ある場合を考光る。このとき， $p$ について次のようなことがいえる。

重相関係数 $R$ と決定係数 $R^{2}$ は, 説明変数の数 $p$ が大きなれば, たとえわずかでも必ず大きくなる。 そして, $p$ が $p=n-1$ に達すると， $R=1$ となり，説明変動率は $100 \%$ になる。

したがって，pが大きい注ど説明の程度が良くなるけれども，pが 20〜30 になると，実際には役に 立たない。現実には, せいぜい $4 \sim 6$ どまりであろう。そこで, ぞの変数を説明変数として選ぶかが重 要な問題になってくるのである。説明変数を選択する基準としては, 次の 3 点が考えられる ${ }^{8)}$ 。

第 1 は, 被説明变数 $y$ の推定・予測に役にたつ变数であること。この場合, $y$ との単相関係数が大き いといらことだけでは不充分であって，他の説明変数との関連も考㝋て，yとの偏相関係数が大きいこ とが必要である。また，ある説明変数が役にたつかどらかは，その変数の変域の大きさに関係する。つ まり, その变数のバラッキが小さければ，その変数の寄与率は小さくなるということである。したがっ て, 醸造に関する知識から役にたつと考えられる変数が, 必ずしもyの推定と予測のために役立つとは 限らない。

第 2 は, 測定と管理がしやすい変数であること。その変数が推定のためにいかに役にたつ変数であっ ても，測定が困難であったり，一定の範囲に管理することが困難な変数であるならば，実際問題として は役にたたない变数となる。

第 3 は, 説明変数相互の間の相関がなるべく小さいことである。

以上のような考方方にとついて，いくつかの変数選択法が考案されている。それらを簡単に紹介し よう。

第 1 は，变数指定法と呼ばれる方法である。いま利用できる説明変数が $p$ 個あるとき，前述した選択 の 3 つの基準に適合する $r$ 個（ただし $r<p ）$ の变数を選ぶ。

第 2 は, 総当り法と呼ばれ, $p$ 個のなから $r$ 個を選ぶすべての組合せについて, 重回帰式を求め, 最 良の式を採用する方法である。その組数は， $2^{p}-1$ であり， pが大きくなると組数が大変に大きくなる ので，pの小さいときしか実用的ではない。

第 3 は，逐次選祄法と呼ばれ，総当り法よりも実用的である。逐次選択法には，さらにいくつかの方 法が含まれる。その 1 つである変数増加法とは, 变数 1 個から出発して, 各段階で寄与率の増加が最大 となるような変数を1個ずつ増加してゆく方法である。ただし，このときどの段階で打切るかといら， 打切り基準をきめておかなければならない。

また，変数減少法とは，最初に $p$ 個の变数をすべて含めた重回帰式をつくり，それから説明変数を1 個ずつ除いていく方法であって，この場合にも打切り基隼が問題になる。

さらに, 変数恉減法とは, 変数増加法と減少法の久点を補うように工夫された方法であって, 変数を 増加していく各段階毎に, すでに取入れた変数を，必要ならば追い出しながら増加していく方法であ る。

（例11）ワインの品質の推定式；佐藤は，ワインの品質の綜合評価に対して，香や味などの各項目が どのような重みで寄与しているかを知るために, 品質の綜合評価の官能值 $y$ 被説明変数とし, 色に対 する官能值 $x_{1}$, 透明度に対する官能值 $x_{2}$, 香に対する官能值 $x_{3}$, 味に対する官能值 $x_{4}$, その他の官能 值 $x_{5}$ などを説明変数として重回帰式を求めた ${ }^{10)}$ 。

（式 8 ）治， $x_{5}$ を除いた变数指定法による場合，（式 9 ）は，逐次選択法（階段的回帰法）による場合 であって，それぞれ罢ることがわかる。

$$
\begin{gathered}
y=0.086 x_{1}+0.127 x_{2}+0.262 x_{3}+0.681 x_{4}+0.312 x_{5}-0.031 \\
R^{2}=0.9692 \\
y=0.076 x_{1}+0.141 x_{2}+0.318 x_{3}+0.809 x_{4}-0.259
\end{gathered}
$$




$$
\begin{aligned}
R^{2} & =0.9631 \\
y=0.128 x_{2}+0.247 & x_{3}+0.776 x_{4}+0.294 x_{5}+0.0005 \\
R^{2} & =0.9660
\end{aligned}
$$

標準偏回帰係数：(例 9 )で示した清酒の味の濃淡を推定する(式 5 )を再びとりあげてみよう。この式 で, 説明変数 $S$ の重み（偏回帰係数）は 0.42 であり, Aの重みは 1.88 であるから, 味の濃淡に対する 寄与の程度は， $S$ ょりもAの方が大きいと考えるならば，それは䛊りである。

なぜならば， $S$ とAの測定の単位の単位を变觉ると，その重みも変わるからである。たと壳ば， $S$ は $100 \mathrm{~m} l$ の清酒中の $\mathrm{g}$ て表示されているが，これを $\mathrm{kg}$ に変えるならば，測定値自身は 1,000 分の 1 にな るから重みは 1, 000 倍になり， $S$ の重みの方が $A$ のそれよりもはるかに大きくなってしまう。

このよらな不都合を除くためには，各变数を規準化（標準化）する必要がある。規準化とは，もとの 変数からその变数の平均值を引き, さらにその標準偏差で割ることによって, 新しい変数に変換するこ とである。すなわち，もとの被説明変数 $y$ を $y^{\prime}$ に, 説明変数 $x_{i}$ を $x_{i}{ }^{\prime}$ に, 次式によって変換する。

$$
y^{\prime}=\frac{y-\bar{y}}{s_{y}}, \quad x_{i}{ }^{\prime}=\frac{x_{i}-\bar{x}_{i}}{s_{i}}
$$

ただし， $\bar{y}, \bar{x}_{i}$ はそれぞれの平均值， $s_{y}, s_{i}$ はそれぞれの標準偏差であり，平均值を引くことは，変数 の平均值を 0 とし, 標準偏差で割ることは变数の分散を 1 にすることおよび測定の単位に無関係にする ことを意味する。このように変換した変数について求めた重回帰式を,

$$
y^{\prime}=a_{1}{ }^{\prime} x_{1}{ }^{\prime}+a_{2}{ }^{\prime} x_{2}{ }^{\prime}+\cdots+a_{p}{ }^{\prime} x_{p}{ }^{\prime}
$$

と書くとき，この $a_{1}{ }^{\prime} \sim a_{p}{ }^{\prime}$ を標準偏回帰係数と呼ぶ。そしてこの回帰式を標準型，もとの回帰式を原型 といら。この $a_{1}{ }^{\prime} \sim a_{p}{ }^{\prime}$ は, 測定の単位に無関係になっている。したがって, 説明変数 $x_{i} の y へ の$ 寄与 率を比較するときには，標準偏回帰係数を比較する方がよい。ただし， $x_{i}$ 相互間に相関が大きいときに は，この係数だけでは充分ではないる。

（例 12） ワイン評価項目の重みづけ；(例 11)で示した（式 9)は，原型であり，これを標準型で示す と次のようになる ${ }^{10)}$

$$
\begin{aligned}
\left(\frac{y-0.590}{1.141}\right) & =0.073\left(\frac{x_{1}-1.100}{1.097}\right)+0.117\left(\frac{x_{2}-0.883}{0.949}\right) \\
& +0.246\left(\frac{x_{3}-0.387}{0.883}\right)+0.681\left(\frac{x_{4}-0.640}{0.961}\right)
\end{aligned}
$$

この式の標準偏回帰係数から，各項目に対寸る重久を百分率として求めると，6.5, 10.5, 22.0,

\begin{tabular}{|c|c|c|c|}
\hline 法 & 色 透明度 & 香 & 味 \\
\hline & $\begin{array}{rr}6.5 \quad 10.5 \\
\end{array}$ & 22.0 & 61.0 \\
\hline 重回㷎式（12）上り & 17.0 & & \\
\hline 山梨県食工試 & $\underbrace{10 \quad 10}_{20}$ & 30 & 50 \\
\hline Ernst Klen & $\underbrace{10 \quad 10}_{20}$ & 20 & 50 \\
\hline W.V. Cruess & $\underbrace{}_{25}$ & 25 & 50 \\
\hline 数值配分法 & $\underbrace{17.6 \quad 11.9}_{29.5}$ & 31.6 & 38.9 \\
\hline
\end{tabular}
61.0となる。これを今までに提唱されている, 経験的な方法によってきめられた重みと比較すると, 第 3 表に示すように, Ernst Klenk の方法とよく一致する。

\section{数量化 I 類}

重回帰分析の場合は, 説明变数も被説明変数もともに距離尺度である。しかしながら, 被説明変数は

第 3 表 赤ドライワインの綜合評価値に 刘する各項目の重みづけ 距離尺度であるが, 説明変数が分類尺度あるいは順位尺度 の場合には, 数量化 I 類と呼ばれる方法を使う。

この方法は, 重回帰分析と同様に最小 2 乗法の考方方に もとついているが, ただしこの場合, ダミ一変数という新 しい変数を導入する必要がある。ダミ一変数については数 量化 II 類の項で説明することにする。

\section{5. 判別する}

\section{判別分析法}

考え方：前号の(例 4)では, 日光によって着色しやすい 清酒と, しにくい清酒を判別する目的に役立てるために, 
22 種類の酒について, キヌレン酸 $\left(x_{1}\right)$, デフェリフェリ クリシン $\left(x_{2}\right)$, マンガン $\left(x_{3}\right)$, チロシン $\left(x_{4}\right)$ を測定し, 日光に当てたときの増色量との関係から, 次のような判 別式をつくった 。

$Z=x_{1}+0.02435 x_{2}+2.745 x_{3}+0.00412 x_{4}$ （式 $1 ）$

そして， $Z \geq 11.16$ の酒は日光着色しやすい酒である と判定し， $Z<11.16$ ならば日光着色しにくい酒である と判定するのである。これを判別分析法といい，(式 1 ) を判別式あるいは判別関数という。

また， $x_{1} \sim x_{4}$ は説明変数であり，距離尺度に属する。 $Z$ は被説明変数であり, 分類尺度あるいは順位尺度に属 する。さらに, $Z$ は $x_{1} \sim x_{4}$ の合成变数とみることもで きる。

さて, この判別式の意味をさらによく理解するため に，次のような仮空例を示すことにしよう。すでに前述 したように, 清酒の甘口・辛口は, グルコース量と酸度

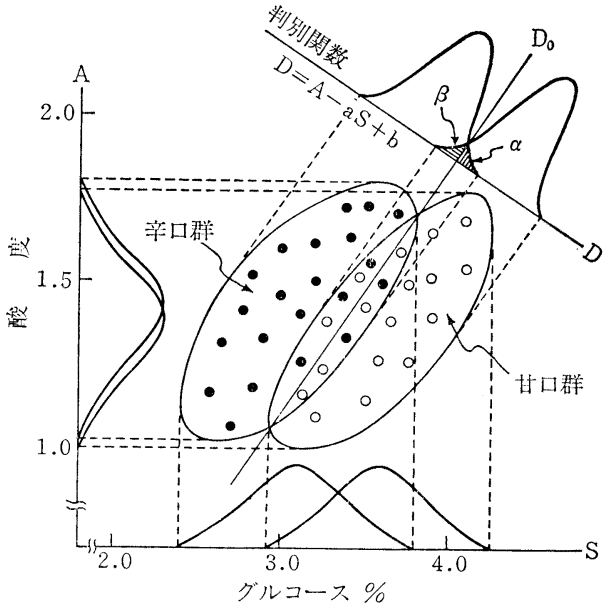

第 7 图 $Z$ 度数, $S(ク ゙ ル コ ー ス \%) と A$ (酸 度）によって、甘ロと辛口を判別する 仮想模型

によって, 約 $80 \%$ 説明することができる。そこで, 多数の清酒を, 横軸にグルコース\%Sをとり縦軸 に酸度 $A$ をってプロットしたのが第 7 図である。

これらの清酒は, 專門パネルの官能検査によって甘口群（白丸）と辛口群（黒丸）とにわ忷られてい

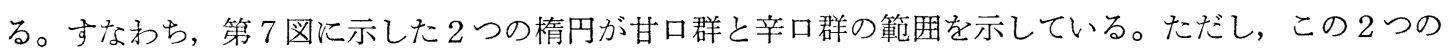
棈円は, 完全に分離しているわけではなく, 一部分が重なっている。これは, 清酒の甘ロ・辛ロがグル コースと酸度ばかりでなく，苦味成分や香気成分にも影響されるからであると考えれば理解しやすいで あろら。

いま，甘口・辛口を判別するために，酸度 $A$ だけで判別しようとするならば，分布が注とんど重なっ ているために不可能といえよう。また, グルコース\%Sだけで判別しよらとしても, 分布の重なりが大 きいので，かなりの誤差を覚悟しなければならない。

そこで，AとS $S$ 適当な重みをかけて合計した合計点 $D=A-a S+b$ の分布を求めると, 四のように 2 群怯大部分が分離して, 重なりの部分は小さくなる。

换言するならば，甘・辛の 2 群が最もよく分離できるように（2 群の平均值間の距離が最も大きくな るように)，椿成した合成変数 Dをつくることが判別分析法である。

第 4 表 判別函数を用いた結果

\begin{tabular}{|c|c|c|c|c|c|}
\hline \multicolumn{3}{|c|}{ 惹色しやすいグループ } & \multicolumn{3}{|c|}{ 萫色しにくいグループ } \\
\hline$\Delta \mathrm{OD}_{420^{30}}(h \nu)$ & Z & 判 定 & $\Delta \mathrm{OD}_{420^{30}}(h \nu)$ & Z & 判 定 \\
\hline .367 & 13.35 & 0 & .297 & 13.33 & $x$ \\
\hline .364 & 13.59 & 0 & .293 & 11.86 & $x$ \\
\hline .357 & 12.38 & 0 & .293 & 12.46 & $x$ \\
\hline .353 & 13.22 & 0 & .237 & 9.11 & 0 \\
\hline .350 & 12.96 & 0 & .222 & 10.18 & 0 \\
\hline .344 & 12.10 & 0 & .220 & 8.56 & 0 \\
\hline .340 & 12.18 & 0 & .218 & 9.77 & 0 \\
\hline .336 & 12.67 & 0 & .198 & 8.24 & 0 \\
\hline .327 & 12.79 & 0 & .185 & 8.21 & 0 \\
\hline .327 & 12.39 & 0 & .150 & 7.01 & $\mathrm{O}$ \\
\hline .315 & 11.60 & 0 & .149 & 7.61 & 0 \\
\hline
\end{tabular}

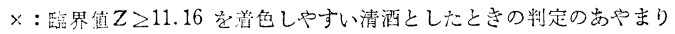
$\triangle \mathrm{OD}:$ 日光管色增加量
第 5 表 黒野らの評価式

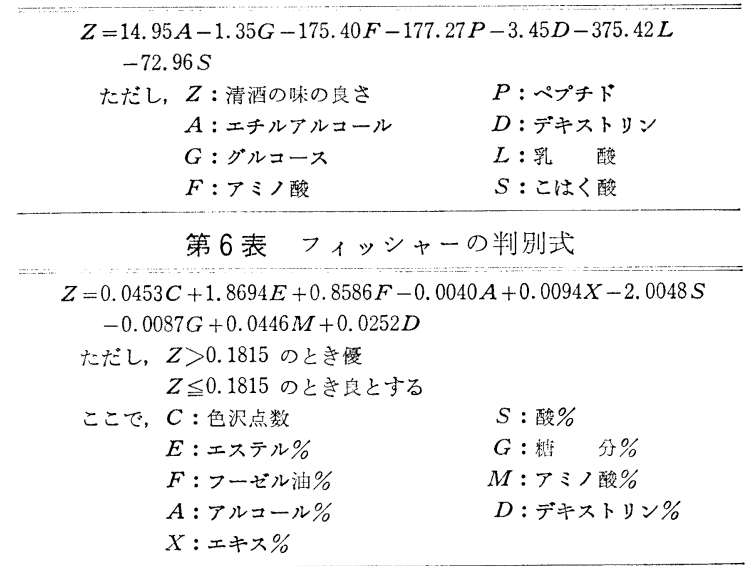


第 7 表 調査の結果

\begin{tabular}{|c|c|c|c|c|}
\hline 対象者 & $\begin{array}{l}\text { 嗜 好 } \\
(y)^{2}\end{array}$ & $\begin{array}{c}\text { 飲酒量 } \\
\left(x_{1}\right)\end{array}$ & $\begin{array}{c}\text { 居住地 } \\
\left(x_{2}\right)\end{array}$ & $\begin{array}{c}\text { 年 令 } \\
\left(x_{3}\right)\end{array}$ \\
\hline 1 & 甘 & 1合以下 & 六大都市 & 20 代 \\
\hline 2 & 甘 & $2 \sim 3$ 合 & " & 30 代 \\
\hline 3 & 辛 & 4 合以上 & 中小都市 & 40 以上 \\
\hline 4 & 甘 & 1 合以下 & 農 村 & 30 代 \\
\hline 5 & 辛口 & $2 \sim 3$ 合 & " & 40 以上 \\
\hline$\vdots$ & & $\vdots$ & $\vdots$ & $\begin{array}{l}\vdots \\
\vdots \\
\vdots\end{array}$ \\
\hline 100 & 甘 & $2 \sim 3$ 合 & 中小都市 & 20 代 \\
\hline
\end{tabular}

第 8 表 質問項目（アイテム）と選択 肢（カテゴリ一）

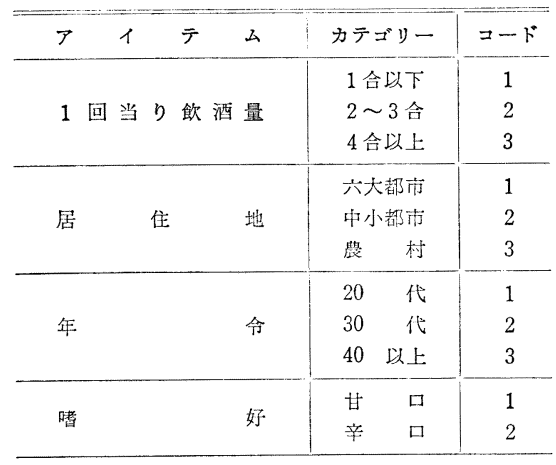

第 9 表 コード化した調查結果

\begin{tabular}{c|c|c|c|c}
\hline 対象者 & $\begin{array}{c}\text { 㬐 好 } \\
(y)\end{array}$ & $\begin{array}{c}\text { 飲酒最 } \\
\left(x_{1}\right)\end{array}$ & $\begin{array}{c}\text { 居住地 } \\
\left(x_{2}\right)\end{array}$ & $\begin{array}{c}\text { 年 } \\
\left(x_{3}\right)\end{array}$ \\
\hline 1 & 1 & 1 & 1 & 1 \\
2 & 1 & 2 & 1 & 2 \\
3 & 2 & 3 & 2 & 3 \\
4 & 1 & 1 & 3 & 2 \\
5 & 2 & 2 & 3 & 3 \\
$\vdots$ & $\vdots$ & $\vdots$ & $\vdots$ & $\vdots$ \\
$\vdots$ & $\vdots$ & $\vdots$ & $\vdots$ & $\vdots$ \\
$\vdots$ & $\vdots$ & $\vdots$ & $\vdots$ & $\vdots$ \\
100 & 1 & 2 & 2 & 1 \\
\hline
\end{tabular}

穊 10 表 新しい变数（ダミ一变数）の設定

\begin{tabular}{|c|c|c|c|c|c|}
\hline むとの変数 & 新しい変数 & 估 & 定 & E & 義 \\
\hline 飲 滩 量 & $z_{1}$ & $\begin{array}{l}1 \\
0\end{array}$ & 1 回当り & $\begin{array}{l}\text { 饮酒量が, } \\
\text { " }\end{array}$ & $\begin{array}{l}\text { 1合以下である場合 } \\
\text { 1合以下でない場合 }\end{array}$ \\
\hline$x_{1}$ & $z_{2}$ & $\begin{array}{l}1 \\
0\end{array}$ & & " & $\begin{array}{l}2 \sim 3 \text { 合である場命 } \\
2 \sim 3 \text { 合でない場合 }\end{array}$ \\
\hline \multirow{2}{*}{$\begin{array}{lll}\text { 居 } & \text { 住 地 } \\
& x_{2} & \end{array}$} & $z_{3}$ & $\begin{array}{l}1 \\
0\end{array}$ & \multicolumn{3}{|c|}{$\begin{array}{c}\text { 居住地が，六大都荫である場合 } \\
\text { " } \quad \text { 六大都芇でない場合 }\end{array}$} \\
\hline & $z_{4}$ & $\begin{array}{l}1 \\
0\end{array}$ & " & \multicolumn{2}{|c|}{$\begin{array}{l}\text { 中小都市である場合 } \\
\text { 中小都市でない場合 }\end{array}$} \\
\hline \multirow{2}{*}{ 年 $x_{3}$ 令 } & $z_{5}$ & $\begin{array}{l}1 \\
0\end{array}$ & $\begin{array}{l}\text { 篮令が, } \\
\text { "I }\end{array}$ & \multicolumn{2}{|c|}{$\begin{array}{l}20 \text { 代である場合 } \\
20 \text { 代でない場合 }\end{array}$} \\
\hline & $z_{6}$ & $\begin{array}{l}1 \\
0\end{array}$ & " & \multicolumn{2}{|c|}{$\begin{array}{l}30 \text { 代である場合 } \\
30 \text { 代でない場合 }\end{array}$} \\
\hline
\end{tabular}

（例13）判別の誤り；前述した(式 1)によって判別した結 果を第 4 表に示した ${ }^{3)}$ 。即ち，この例では着色しやすいグル 一プの酒を着色しにくい酒と䛊判別した試料が 3 個であるか ら，誤判別の確率は $100 \times 3 / 22=13.6 \%$ である。

しかし一般には, 判別の誤りは 2 種類ある。たと党ば第 7 図に示したように，辛口酒を甘口酒と誤判定する確率 $\alpha$ と, 甘口酒を辛口酒と誤判定する確率 $\beta$ の 2 種類があり, 通常は $\alpha=\beta$ となるように臨界值 D。をきめる。そして， $\alpha+\beta \leq$ 0.05 あるいは $\alpha+\beta \leq 0.10$ であることが望ましい。

（例 14）黒野の評価式とフィッシャーの判別式；1936 年 つまり昭和 11 年の醇造論文集に, 黒野は「清酒の成分と科 学的審査」と題する論文を発表している ${ }^{11)}$ 。これは, 全国 の約 800 点に及ぶ清酒を集めて，これをのべ 100 人日以上の 労力を使って分析し，ソロバンと手回しの計算機で見当もつ かない程の時間を費やして計算し，その結果を 100 ページを 超觉る長文にまとめた労作である。

この研究の目的は, 酒の香味を感覚器によって評価する官 能検查法を, 化学成分によって評価する方法に湿き換えよう とするところにあった。すなわち，Zを清酒の品質の良さと 乙, 大文字を $A \sim S$ 化学成分值とするとき,

$$
Z=a A+b G+c F+d P+e D+f L+g S
$$

のよらな評価式を求めることである。ここで $Z$ の值は官能検 査によってきめることができるし，A〜S は化学分析によっ て求めることができるから, 結局, 小文字の $a \sim g$ の值をき めることが必要林。そこで黒野らは，7個の未知数をき めるために， 7 個の方程式をつくり，この連立方程式を解い て，第 5 表に示したような評価式を得たのである。

この評価式の精度を調べてみると，清酒の品質の優と可の 差はかなり良く判別できるけれども，優と良の差は全く判別 できないといら結論であって，そのためにこの評価式は実用 化されていない。この精度の悪さの理由には色々教克られる 
が，その大きな理由の 1 つは，黒野らが採用した数学的手段が最良ではなかったといらことにあるら。

実は，黒野らの論文が発表されたと奇しくも同年に，R.A.フィッシャーが，優生学の専門誌上に判 別分析法を発表しているのである。幸いに，黒野らのデータがそっくり記録として残されているので, フィッシャーの方法によって筆者が求めたのが, 第 6 表に示した判別式である。この判別式によれば, 優を良と誤判定する確率が 10\%，良を優と誤判定する確率も10\%であって，黒野らの評価式よりもは るかに精度が良くなっている。

\section{数量化 II 類}

判別分析では, 説明変数が距離尺度で, 被説明変数が分類尺度あるいは順位尺度であった。数量化II 類は, 説明変数も被説明変数もともに分類尺度あるいは順位尺度であるときの, 判別分析法であるとい 党る。

したがって，数量化II類の場合も，次のような判別式をつくることが目的である。

$$
f=a_{1} z_{1}+a_{2} z_{2}+\cdots+a_{p} z_{p}
$$

（例 15） 甘口党と辛口党の判別; 昭和 51 年の日本酒造組合中央会の調查では, 清酒の甘辛に対する 消費者の嗜好は, 甘口党が約 5 割, 辛口党が約 3 割, どちらでもよい人が約 2 割となっている。これら の嗜好には, 種々の要素が原因になっていると考学られるが, 特に, 1 回当り飲酒量 $x_{1}$, 居住地 $x_{2}$, 年令 $x_{3}$ の 3 要素が大きく影響していると思われる。

そこで, この 3 要素を知ることによって, 甘口党, 辛口党を判別する式を作る目的で, 調査を行なっ た仮空例を考えてみよう。その結果を第 7 表に示す。

第 8 表は, その調查に用いたアイテム（項目）とカテゴリー（範ちゅう）を示し，さらにこれらに対 してつけたコード (符号) を示す。第 7 表に示した調查結果を，このコードによってコード化したのが 第 9 表である。

この第 9 表に示したデータについて, 判別分析と同じ考方方で判別式をつくればよいように思われる 斿孔゙も, 飲酒量 $x_{1}$ と年令 $x_{3}$ は順位尺度であり, 居住地 $x_{2}$ は分類尺度であるから, 数值間の加隇乗除 には意味がない。

そこで，第 10 表に示した新しい变数を導入することにする。これらの新変数 $z_{1} \sim z_{6}$ は 1 か 0 かどち らかの值しかもたない特別な変数であって，ダミー変数あるいは1-0 型変量などと呼ぶ。

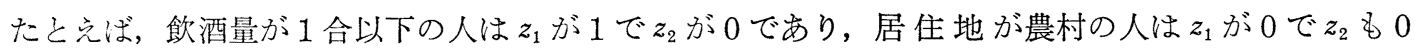
であり，年令が 30 代の人は $z_{5}$ が 0 で $z_{6}$ が 1 である。これらのダミ一変数を使った調查結果を，第 11 表に示した。

ダミ一変数が 0 と 1 の值しかとらないといら特殊な変数であるので，四則演算が可能になる。したが って，判別式を求めるときと同様に扱らことが可能になるのである。

(つづく)

\section{文献}

8）奥野忠一，久米均，芳賀敏郎，吉沢正：多変量解析法，日科技連 (1971)

9）佐藤信，大場俊辉，高橋康次郎，杉谷守：清酒の熟成による香味の 変化関する研究 (第 18 報), 本誌, $73,11,878$ 882 (1978)
10）佐藤信：ワインの品質の綜合評価，第 2 回日科技連官能検査シンポ ジウム, (1972)

11）黑野勘六, 他酸造試験所員一同 : 清酒の成分と科学的審査, 醮造論 文集，日本醇友会，4，120 (1936)

12）佐藤信：官能検查入門，日科技連 (1978) 